\title{
Characterization of a group of elderly people and the demographic aging profile of Mexico
}

\author{
Abstract \\ Objective: To characterize a group of Mexican elders it based on the national \\ demographic aging.
}

Material and methods: A quantitative, observational, descriptive, cross-sectional and prospective study was carried out from May to August 2016, with a non-probabilistic sample for the convenience of 11 elders. The information was collected through a Sociodemographic Identification Card, descriptive analysis.

Results and discussion: The average age of 70.09 years $(\min =60, \max =78) ; 81.8 \%$ are women, in education $63.6 \%$ of the elderly have a higher education; regarding work activity, $63.6 \%$ are retired; $36.4 \%$ are divorced or separated; $90.9 \%$ are Catholics; $81.8 \%$ receive pension; $45.5 \%$ live with their children. Life expectancy in Mexico is 75.6 years, $56.3 \%$ of Mexicans are elderly women, about $18 \%$ of the elderly in Mexico have a university degree. The $44 \%$ of the elderly do not work, $16.2 \%$ of them are retired. In the country, $37.9 \%$ of the women are divorced and $90 \%$ of the elderly are Catholics.

Conclusion: Aging is characterized by feminization and increased life expectancy. Another relevant fact is that older people do not work, a small percentage receive a retirement pension, which can lead to the lack of resources to have quality of life in the aging.

Keywords: demographic aging, aged
Volume 5 Issue I - 2018

\author{
Raúl Fernando Guerrero-Castañeda,' Tânia \\ Maria de Olvia Menezes, ${ }^{2}$ Ma Guadalupe \\ Ojeda Vargas ${ }^{3}$ \\ 'Department of Clinical Nursing, University of Guanajuato, \\ México \\ ${ }^{2}$ Associate Professor, Federal University of Bahía, Brazil \\ ${ }^{3}$ Department of Nursing and Obstetrics, University of \\ Guanajuato, México
}

Correspondence: Raúl Fernando Guerrero-Castañeda, Department of Clinical Nursing, Division of Health Sciences and Engineering, University of Guanajuato, México, Tel 4615985922 Email ferxtom@hotmail.com

Received: August 04, 2017 | Published: January 04, 2018

\section{Introduction}

Aging globally has grown rapidly in recent years; this is a consequence of multiple factors, the most notable of which are the reduction of the birth rate and the increase in life expectancy. Globally there were 901 million people aged 60 and over, representing the $12.3 \%$ of the population, which is also reported by the World Health Organization (WHO). ${ }^{1,2}$ In Mexico, the situation of aging is similar to that of the world, according to statistics, 12.2 million elderly people live in this country, representing $9.6 \%$ of the national population. The increase in life expectancy will bring great demands, from health, education, quality of life, economy and social protection; since the situation of Mexican elders reflects diversity and heterogeneity, these differences are even more visible from a gender perspective, which should generate an effort to improve policies for this age group. ${ }^{4-7}$ It is important to visualize the characteristics of the elderly in diverse contexts of study in health to highlight the needs and to glimpse the possible interventions to implement. The objective of this article is to characterize a group of Mexicans elderly based on the national demographic aging. Preliminary results of a phenomenological study carried out in Mexico are presented, it is intended to contextualize the study group and analyze the national demography.

\section{Material and methods}

Quantitative, observational, descriptive, transversal and prospective study. It was carried out in a group of elderly people from the city of Celaya, Guanajuato, Mexico from May to August 2016. Non-probabilistic sample for convenience $(n=11)$, (participants are part of a nursing phenomenological study). The collection of data through a Sociodemographic Identification Card with six open questions. Information capture was carried out in the SPSS Vs. 22, descriptive statistics were performed with frequencies and percentages. Study approved by the Research Committee of the Division of Health Sciences and Engineering of the Campus Celaya-Salvatierra of the University of Guanajuato.

\section{Results and discussion}

The average age was 60 years, minimum 60 years and maximum 78 years; the $81.8 \%$ are women and $18.2 \%$ are men; $63.6 \%$ have undergraduate studies; the $63.6 \%$ of the participants are retired, the $27.3 \%$ is considered dedicated to housework. The $81.8 \%$ receive a pension, whether for retirement or widowhood. In relation to marital status, the $36.4 \%$ are divorced or separated; of the participants, the $90.9 \%$ profess the catholic religion; the $45.5 \%$ of the elderly live with children, while $36.4 \%$ live alone. The analysis regarding the demographic situation of Mexico in relation to the elderly reflects that the physical age is characterized by the own changes of the aging, changes that in a heterogeneous way depend on multiple factors. Chronological age is related to the social basis for legislation, especially pensions. The age of 60 is considered an elder in Mexico. ${ }^{8}$ Life expectancy for Mexicans by 2015 is 75.5 years, increasing by 43 years for women and 39 for men..$^{910}$ The Mexican elder aspires to live 22 years later after 60 years old, 17.3 years of those 22 will be years of healthy living. ${ }^{3}$ For Guanajuato, men and women had in 2010 with a life expectancy of 73.1 and 77.8 years at birth, respectively. ${ }^{11}$ The face of Mexican old age has a female characterization, in Mexico in 2010 , the percentage of elderly women was $53.4 \%$, slightly higher than men, ${ }^{10}$ per 100 women there we $87 \mathrm{men}$, this is related in turn to Life expectancy in relation to gender, since women tend to live longer than men; By 2014 life expectancy for women was 77.5 years and for 
men 72.1 years. ${ }^{9}$ In Guanajuato in 2010 for every 100 women there were 79.3 men; life expectancy was 73.10 years for men and 77.8 for women, ${ }^{11}$ so it is important to visualize health in relation to the gender perspective. In education, in Mexico in 2010 , the $74.3 \%$ of the elderly were literate, while $24.6 \%$ had no education at all. The study years for the population aged 60-64 were only 5.8 years of study, $11.4 \%$ had a higher education degree at the undergraduate or postgraduate level, compared to 4.1 years in the $65-84$ age group, with $6.6 \%$ who had higher or postgraduate degrees. The $50 \%$ in both groups had complete primary education. ${ }^{10}$ In Guanajuato, only $3.4 \%$ of the elderly had a high school education, $52.8 \%$ had no education. ${ }^{12}$ With respect to the labor situation, in 2014 in Mexico a third part of the elderly worked, the $50.8 \%$ were men. The $8.7 \%$ of women are retirees or pensioners, while $25.1 \%$ of men are in this situation. ${ }^{9}$ In Guanajuato, by 2013 only $6.3 \%$ of the elderly is inactive for retirement, ${ }^{11}$ the $29.8 \%$ of the elderly was economically active, one third of the total. ${ }^{10}$ Nationally by $2010,66.6 \%$ of the elderly were economically inactive, while $31.6 \%$ were active. Of the non-economically active, $25.1 \%$ is due to being retired. $49.4 \%$ of the assets economically do it on their own account while $36.9 \%$ receive a salary, ${ }^{10}$ which increases the vulnerability of the elderly, since $36.6 \%$ work an average of 33 to 48 hours a week and $26.9 \%$ do so by overcoming The 48 hours of workday per week. ${ }^{10}$

In Mexico, only $8.7 \%$ of women receive pensions for widowhood ${ }^{9}$, while in 2013 in Guanajuato, $23.7 \%$ of the elderly received a pension, of which $43.4 \%$ received it for years of service. The "Pension Program for Older Adults" is a program of the Federal Government of Mexico, whose support is $\$ 27$ per month, ${ }^{13}$ an average of $\$ 1$ per day, the minimum salary in Mexico is $\$ 4.2$ per day, which calls into question the economic vulnerability of the elderly. The marital situation reflects that in Mexico in 2014, 67\% of men and $42.2 \%$ were married, $8.7 \%$ of men and $4 \%$ of women were separated or divorced. ${ }^{9}$ In Guanajuato $55.6 \%$ were married by 2013 , compared to $32.8 \%$ who were widowed. ${ }^{14}$ Generally and in relation to gender, women are the ones who do not usually get remarried when separated or widowed, unlike men who do it more frequently. ${ }^{15}$ About the religion in Mexico, $86.5 \%$ of the elderly profess the Catholic religion. ${ }^{10}$ The adherence to some religious beliefs is framed as characteristics of the stage of old age due to spiritual connections that tend to increase with age. ${ }^{16-}$ ${ }^{18}$ In Mexico in 2014, the elderly lived in family homes, $49.7 \%$ in nuclear households, followed by extended households (38.1\%), women living less frequently in nuclear households and more in extended households (47\%). ${ }^{9}$ In Guanajuato by 2012 , there were two households out of ten where an older adult lived, $43.4 \%$ of households were expanded, $41.9 \%$ were nuclear, and only $14.7 \%$ were singleparent households. ${ }^{14}$ The family also supports the emotional and social aspect of the elderly, provides empathy, affection and love, which is generally the first level of contact of the elderly, after the couple..$^{19,20}$ It is necessary to know the characteristics of the elderly, the importance and impact it generates at the level of nursing care and health care. The limitations of the study were the number of participants being an analysis part of a qualitative study and carried out in two scenarios, which does not allow to generalize the characteristics, however, it allows an approach to the continuous analysis of the characteristics of the elderly in different contexts And its impact on the population dynamics of Mexico, which has an impact on the health of the elderly.

\section{Conclusion}

The profile of the elderly is comparable to the national demographic profile, where a female face predominates in old age, an age that can exceed the age of life expectancy. Even in the country a large number of elders have basic education, while small groups may have higher levels of education. A large percentage of the elderly are in retirement and although they receive a pension, it differs because a large part receives a non-contributory pension, that is, a government that does not guarantee an optimal quality of life. Elders generally live in nuclear or extended households. Old age tends to be heterogeneous, not only in its physical characteristics, but in relation to other factors such as the economic or family situation, or, in quality of life. Mexico still has the important task of creating policies of permanent aging and also improves the situation of this age group.

\section{Acknowledgements}

To each of the groups that participated in the study.

\section{Conflict of interest}

The authors declare no conflict of interest.

\section{References}

1. 10 facts on ageing and health. OMS. Geneva, Switzerland: World health organization; 2007.

2. Help Age International. Global Age Watch Index 2015: Insight report. London: 2015.

3. Help age international. Global Age Watch Index 2015: Report Card México. Age Watch report card México: 2015.

4. Monteverde M, Tomas S, Acosta LD, et al. Population agind and magnitude of dependency in Argentina and México: Comparative perspective with Spain. Rev Latinoam Población. 2016;(18):135-154.

5. Peña MC, Ones DG, Cruz RV. Envejecimiento poblacional como reto de la ciencia, la técnica y la sociedad. Rev Habanera Ciencias Médicas. 2015. 6 p.

6. Instituto nacional para las personas adultas mayores. Por una cultura de envejecimiento. México, DF: INAPAM: Springer; 2010.

7. García Ramírez JC. Diagnóstico situacional del envejecimiento en México desde los derechos humanos y la política pública. Entreciencias diálogos en la Soc del Conoc. 2016;4(10):243-262.

8. Secretaría de Salud México. Norma Oficial Mexicana NOM-167SSA1-1997, Para la prestación de servicios de asistencia social para menores y adultos mayores. México: Springer; 1997.

9. Instituto nacional de las mujeres. Situación de las personas adultas mayores en México: 2015.

10. Instituto nacional de estadística y geografía. Perfil sociodemográfico de adultos mayores, México: Springer; 2014.

11. Consejo nacional de población y vivienda. Dinámica demográfica 1990 2010 y proyecciones de población 2010-2030, Cuadernillo Guanajuato, México: Springer; 2014.

12. Instituto nacional para las personas adultas mayores. Perfil sociodemográfico de adultos mayores. México: Springer; 2014.

13. Secretaría de desarrollo social. Pensión para adultos mayores. Pensión para Adultos Mayores.

14. Instituto nacional de estadística geografía e informática. Estadísticas a propósito del Día internacional de las personas de edad (1 Octubre) datos guanajuato; 2014.

15. Montes de Oca Zavala V Viudez. Soledad y sexualidad en la vejez: mecanismos de afrontamiento y superación. Rev Kairós Gerontol. 2011;14(5):73-107. 
16. Costa D, Vieira R, Avellar De Aquino TA. Subjective vitality, meaning in life and religiosity in older people: A correlational study. Trends Psychol. 2016;24(2):495-506.

17. Abdala GA, Kimura M, Duarte YAO, et al. Religiosidade e qualidade de vida relacionada à saúde do idoso. Rev Saúde Pública. 2015;49(55):1-9.

18. Melo CF, Sampaio IS, Souza DLA, et al. Correlação entre religiosidade, espiritualidade e qualidade de vida: uma revisão de literatura. Estud e Pesqui em Psicol. 2015;15(2):447-464
19. Costa AMMR, Lopes RGC. Rede de Suporte Social na Velhice: para além da família e dos amigos. Rev Portal Divulg. 2016;40:110-119.

20. Vento EM, Ulloa EH, Oliva YDR, et al. Caracterización de la percepción de las relaciones familiares de adultos mayores incorporados a círculos de abuelos. Rev Ciencias Médicas La Habana. 2016;21(2):346-356. 